\title{
In Vitro Transcripts of Wild-Type and Fluorescent Protein-Tagged Triticum mosaic virus (Family Potyviridae) are Biologically Active in Wheat
}

\author{
Satyanarayana Tatineni, Anthony J. McMechan, Melissa Bartels, Gary L. Hein, and Robert A. Graybosch
}

First author: United States Department of Agriculture-Agricultural Research Service (USDA-ARS) and Department of Plant Pathology; second and fourth authors: Department of Entomology; third author: USDA-ARS; and fifth author: USDA-ARS and Department of Agronomy and Horticulture, University of Nebraska-Lincoln, Lincoln 68583.

Current address of M. Bartels: Syngenta, 6338 Highway 20/26, Nampa, ID 83687.

Accepted for publication 21 July 2015.

\begin{abstract}
Tatineni, S., McMechan, A. J., Bartels, M., Hein, G. L., and Graybosch, R. A. 2015. In vitro transcripts of wild-type and fluorescent protein-tagged Triticum mosaic virus (family Potyviridae) are biologically active in wheat. Phytopathology 105:1496-1505.

Triticum mosaic virus (TriMV) (genus Poacevirus, family Potyviridae) is a recently described eriophyid mite-transmitted wheat virus. In vitro RNA transcripts generated from full-length cDNA clones of TriMV proved infectious on wheat. Wheat seedlings inoculated with in vitro transcripts elicited mosaic and mottling symptoms similar to the wildtype virus, and the progeny virus was efficiently transmitted by wheat curl mites, indicating that the cloned virus retained pathogenicity, movement, and wheat curl mite transmission characteristics. A series of TriMV-based

expression vectors was constructed by engineering a green fluorescent protein (GFP) or red fluorescent protein (RFP) open reading frame with homologous NIa-Pro cleavage peptides between the P1 and HC-Pro cistrons. We found that GFP-tagged TriMV with seven or nine amino acid cleavage peptides efficiently processed GFP from HC-Pro. TriMV-GFP vectors were stable in wheat for more than 120 days and for six serial passages at 14-day intervals by mechanical inoculation and were transmitted by wheat curl mites similarly to the wild-type virus. Fluorescent protein-tagged TriMV was observed in wheat leaves, stems, and crowns. The availability of fluorescent protein-tagged TriMV will facilitate the examination of virus movement and distribution in cereal hosts and the mechanisms of cross protection and synergistic interactions between TriMV and Wheat streak mosaic virus.
\end{abstract}

Development of reverse genetics systems revolutionized the study of gene functions of plant RNA viruses (Ahlquist et al. 1984; Boyer and Haenni 1994; Dawson et al. 1986). Infectious cDNA clones, a critical component of the reverse genetics system, facilitate faithful production of in vitro RNA transcripts identical to virion RNA, except for a few additional nonviral nucleotides at the 5' and 3' termini (Ahlquist et al. 1984; Boyer and Haenni 1994). Reverse genetics systems also allowed the use of viruses for transient expression of specialty products and virus induced gene silencing to unravel host gene functions (Burch-Smith et al. 2004; Gleba et al. 2007; Scholthof et al. 1993; Shivprasad et al. 1999). Infectious cDNA clones are available for several members of the family Potyviridae; nonetheless, plasmids harboring cDNAs of most members of the family Potyviridae are known to be toxic to Escherichia coli, causing rearrangement of viral cDNAs (Boyer and Haenni 1994). A variety of methods have been used to overcome potyvirus toxicity to the bacterium such as in vitro ligation of individual cDNA fragments or reverse transcription (RT)-polymerase chain reaction (PCR) amplification of entire genomic RNA, followed by in vitro transcription (Fakhfakh et al. 1996; Stewart et al. 2012), insertion of introns into the viral sequences (Johansen 1996; López-Moya and García 2000), and use of low-copy-number plasmids (Choi et al. 1999).

Triticum mosaic virus (TriMV), a recently reported wheat (Triticum aestivum L.) virus (Seifers et al. 2008), is widespread in the Great Plains of North America (Burrows et al. 2009; Byamukama

Corresponding author: S. Tatineni;

E-mail address: Satyanarayana.tatineni@ars.usda.gov

http://dx.doi.org/10.1094/PHYTO-06-15-0138-R

This article is in the public domain and not copyrightable. It may be freely reprinted with customary crediting of the source. The American Phytopathological Society, 2015. et al. 2013). TriMV is the type species of the genus Poacevirus in the family Potyviridae (Tatineni et al. 2009) with Sugarcane streak mosaic virus (Xu et al. 2010) and Caladenia virus A (Wylie et al. 2012) as definitive and tentative members, respectively. The 10,266-nt single-stranded positive-sense genomic RNA of TriMV is organized similarly to those of Potyvirus, Tritimovirus, and Rymovirus species (Fellers et al. 2009; Tatineni et al. 2009). The genomic RNA is translated as a polyprotein that was presumed to be cleaved into at least 10 mature proteins by $\mathrm{P} 1$ and HC-Pro (in cis) and NIa-Pro (in trans). TriMV differs from other members of Potyviridae in polyprotein amino acid (aa) sequence homology and has an unusually long (739 nt) 5' untranslated region (UTR) (Tatineni et al. 2009). Recently, we determined that the P1 of TriMV is an RNA silencing suppressor and enhancer of pathogenicity (Tatineni et al. 2012). However, the functions of other TriMVencoded proteins are not known. TriMV is transmitted by the eriophyid wheat curl mite (Aceria tosichella Keifer) (McMechan et al. 2014; Seifers et al. 2009). Co-infection of TriMV and Wheat streak mosaic virus (WSMV) is common in wheat fields, as both viruses are transmitted by wheat curl mites (Burrows et al. 2009; Byamukama et al. 2013). The lack of knowledge of TriMV gene functions and the mechanism of synergistic interactions between WSMV and TriMV in co-infected wheat cultivars (Tatineni et al. 2010) warranted the development of an infectious cDNA clone for TriMV. Except for WSMV (Choi et al. 1999), infectious cDNA clones are not available for other eriophyid mite-transmitted plant viruses.

In this study, we report the development of infectious cDNA clones of TriMV in a high-copy-number plasmid. In vitro RNA transcripts from TriMV cDNA clones were infectious on wheat with symptoms similar to those of the wild-type virus, and the progeny virus was transmitted by wheat curl mites. Additionally, both green fluorescent protein (GFP) and red fluorescent protein (RFP) open 
reading frames (ORFs) were independently engineered into TriMV genome between P1 and HC-Pro cistrons with a series of homologous NIa-Pro cleavage peptides. Detection of fluorescent proteintagged TriMV in wheat leaves, stems, and crowns will facilitate the examination of virus movement and distribution in cereal hosts. GFP-tagged TriMV vectors were stably expressed in wheat for more than 120 days and for six serial passages at 14-day intervals by mechanical inoculation and were transmitted by wheat curl mites similar to wild-type virus.

\section{MATERIALS AND METHODS}

Virus source. Wheat seedlings at the single-leaf stage were mechanically inoculated with crude sap extracted from TriMV (isolate Nebraska)-infected tissue as described in Tatineni et al. (2009). For long-term storage, TriMV-infected wheat leaves collected at $14 \mathrm{dpi}$ were stored at $4^{\circ} \mathrm{C}$ under anhydrous calcium sulfate.

Construction of full-length genomic cDNA clones of TriMV. RNA isolated from partially purified TriMV virions (Tatineni et al. 2009) was used as a template for RT-PCR amplification of three overlapping cDNA fragments. Reverse transcription reactions were performed with Avian myeloblastosis virus (AMV) reverse transcription (Roche, Indianapolis, IN) in a $20-\mu l$ reaction volume as described by the supplier. PCR was performed with Pfu Ultra II DNA polymerase in a $100-\mu 1$ reaction and cloned in a modified pUC119 (for fragments I and II) and pGEM-7fZ (Promega, Madison, WI) (for fragment III) (see below). For each cDNA fragment, a minimum of nine independent clones were selected and used to assemble nine independent full-length cDNA clones. The ligation reactions were transformed into $E$. coli strain JM109 (Promega).

cDNA fragment I comprising nt 1 to 2,870 was amplified with a plus-sense primer Tr-27 (5'-GTGGAAGCTTTCTAGATTTA GGTGACACTATAGAAAATTAAAGATCATATTACATAAAA-3', containing the HindIII [in italics] and $\mathrm{XbaI}$ [in boldface] and an SP6 RNA polymerase promoter sequence [underlined] followed by the first $26 \mathrm{nt}$ of TriMV) and a minus-sense primer Tr-28 (5'CAACTCTTAGCACGTGCGGAATCGGAACGA-3', complementary to nt 2,870 to 2,841) (Fig. 1). The RT-PCR fragment was digested with HindIII (engineered in the plus-sense primer) and BssHII (nt 2,831) and ligated into similarly digested modified
pUC119. Fragment II, comprising nt 2,801 to 6,480, was amplified with a pair of primers, Tr-29 (5'-CAAGTAAATGTTAGTTTTTGC GAAGTCGTG-3', corresponding to nt 2,801 to 2,830) and Tr-30 (5'GTTGTCAAGCCAGTTTCACGCGTGTGTACC-3', complementary to nt 6,480 to 6,451 ) (Fig. 1). The RT-PCR product was digested with $B s s \mathrm{HII}$ and NsiI, and ligated into similarly digested modified pUC119. Fragment III, comprising nt 6,401 to 10,266 plus 105 A residues, was amplified with a pair of primers, Tr-31 (5'-ACAATTTGGTAT TACCTTAAGAAGCGTGAA-3' ${ }^{\prime}$, corresponding to nt 6,401 to 6,430 ) and $\operatorname{Tr}-32$ (5'-GAGACCCGGGGCGGCCGCT $(105)$ ACCCCGA CACTATAAAGCTCG-3', complementary to nt 10,266 to 10,246 , followed by $105 \mathrm{~T}$ residues and the NotI [in boldface] and SmaI [in italics] restriction enzyme sites) (Fig. 1). The RT-PCR fragment was digested with $N s i \mathrm{I}$ and SmaI, and ligated into similarly digested pGEM-7Zf (+).

TriMV cDNA fragment III in pGEM-7Zf(+) was released by digesting with $N s i \mathrm{I}$ and $S m a I$, and the insert was ligated into similarly digested fragment I containing clones to obtain fragments I+III. The NsiI and SmaI restriction sites were present in the multiple cloning region of modified pUC119 containing fragment I. Fragment II of TriMV cDNA was released by digesting with $B s s \mathrm{HII}$ and NsiI and ligated into similarly digested fragment I+III clones to obtain full-length cDNA clones of TriMV (Fig. 1).

Construction of GFP and RFP vectors. The heptapeptide cleavage sites located between $6 \mathrm{~K} 1 / \mathrm{CI}$ or $\mathrm{NIb} / \mathrm{CP}$ cistrons were fused to the $3^{\prime}$ end of GFP or RFP ORF by overlap extension PCR (Ho et al. 1989). The cycle 3 GFP or RFP ORF with a cleavage peptide sequence at its $3^{\prime}$ end was precisely inserted between the P1 and HC-Pro cistrons by overlap extension PCR using three individual PCR fragments with 18 to 21 bp overlapping sequences. PCR fragment 1 contained the SP6 RNA polymerase promoter sequence, followed by TriMV sequence through the end of P1 cistron plus the first six codons of GFP or RFP. PCR fragment 2 possessed the last six codons of P1, followed by GFP or RFP ORF with a cleavage site plus the first seven codons of HC-Pro. PCR fragment 3 comprised the last seven codons of GFP or RFP, followed by a cleavage site, plus the HC-Pro cistron sequence until nt 2,870. The three PCR fragments were gel-purified and used as templates for overlap extension PCR. Amplification of PCR fragments 1 to 3 and overlap extension PCR were performed with Herculase II Fusion DNA polymerase (Agilent Technologies, Santa Clara, CA). The

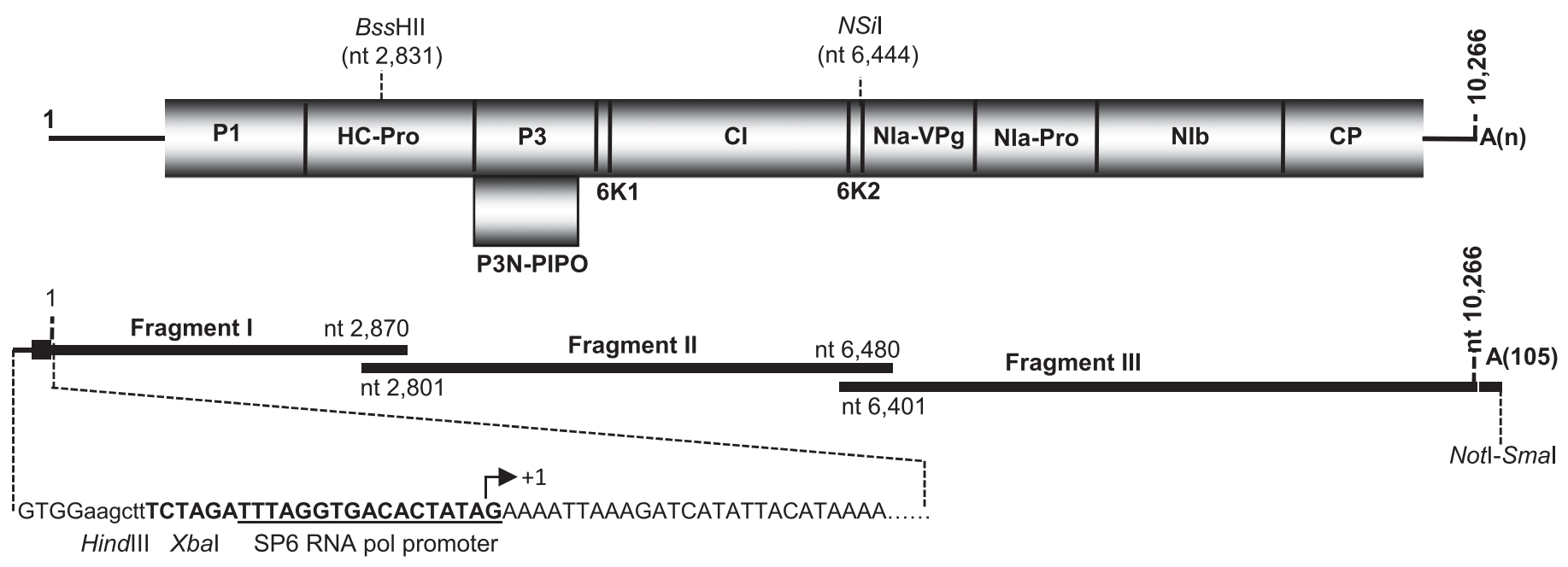

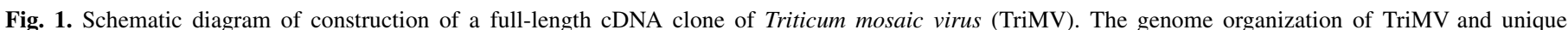

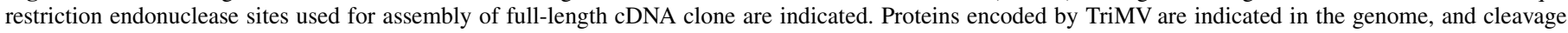

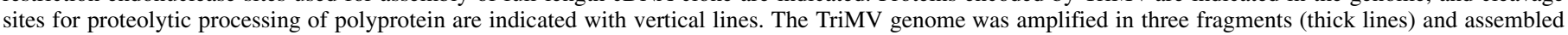

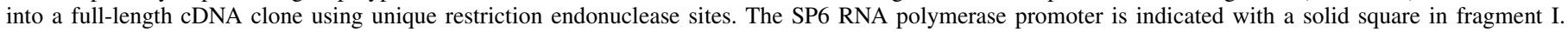

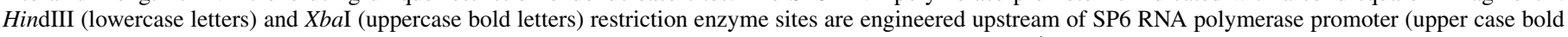

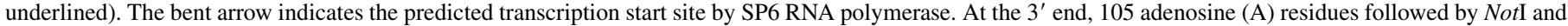
SmaI restriction enzyme sites are introduced. 
overlap extension PCR fragments were digested with XbaI (engineered upstream of an SP6 RNA polymerase promoter sequence in the plus-sense primer) and $B s s \mathrm{HII}$ (nt 2,831) and ligated into similarly digested pTriMV-R.

Plasmid DNA isolation, in vitro transcription, and inoculation of wheat seedlings. Preparation of plasmid DNA from an overnight-grown $E$. coli culture at $30^{\circ} \mathrm{C}$ and in vitro transcription from $1.0 \mu \mathrm{g}$ of NotI-linearized plasmid DNA was described previously (Tatineni et al. 2011). Freshly prepared in vitro transcripts were inoculated onto 12 to 18 wheat 'Tomahawk' seedlings at the single leaf stage as described in Tatineni et al. (2011). Wheat seedlings inoculated with in vitro transcripts were incubated in a greenhouse with 24 to $30^{\circ} \mathrm{C}$ max and 20 to $22^{\circ} \mathrm{C}$ min temperatures with a 14 to $16 \mathrm{~h}$ photoperiod. Inoculated wheat seedlings were observed for symptom development from 7 dpi onwards. At least three independent clones per construct were inoculated to wheat seedlings, and the results of one representative clone per construct are presented.

Nucleotide sequencing. Nucleotide sequencing of full-length cDNA clone pTriMV\#4 and junctions of GFP or RFP with TriMV sequence were verified by sequencing plasmid DNAs at the University of Florida ICBR Core DNA Sequencing Facility using an Applied Biosystems 3730 model sequencer.

Detection of GFP and RFP fluorescence in wheat. Inoculated and upper noninoculated leaves from plants infected with GFP- or RFP-tagged TriMV were examined for the expression of fluorescent protein with a Zeiss Stereo Discovery V12 Fluorescence Microscope (Carl Zeiss MicroImaging, Inc., New York) using GFP or RFP narrow band filters as described in Tatineni et al. (2011). The GFP or RFP fluorescence images were taken using an AxioCam MRc5 camera attached to the fluorescence microscope. Wheat leaves infected with GFP- or RFP-tagged TriMV were also observed under a Nikon A1 confocal system on a Nikon 90i upright fluorescence microscope (Nikon, Tokyo, Japan) for GFP (at $488 \mathrm{~nm}$ excitation and 500 to $550 \mathrm{~nm}$ emission) and for RFP (at $561.4 \mathrm{~nm}$ excitation and 570 to $620 \mathrm{~nm}$ emission).

Protein extraction and western blot analysis. Total proteins were extracted from wheat leaves by grinding $0.4 \mathrm{~g}$ of tissue in liquid nitrogen into a fine powder, followed by maceration in $2 \mathrm{ml}$ of TPE buffer (50 mM Tris-acetate, $\mathrm{pH} 7.4,10 \mathrm{mM}$ potassium acetate, $1 \mathrm{mM}$ EDTA, and $5 \mathrm{mM}$ DTT) containing 1 Complete Mini Protease Inhibitor Cocktail tablet (Roche) per $10 \mathrm{ml}$ of TPE buffer. The extract was mixed with an equal volume of $2 \times$ sample buffer (100 mM Tris-HCl, pH 6.8, 4\% sodium dodecyl sulfate [SDS], $20 \%$ glycerol, 5\% $\beta$-mercaptoethanol, and $0.2 \%$ bromophenol blue), boiled for $3 \mathrm{~min}$, centrifuged at $16,000 \times g$ for $5 \mathrm{~min}$ and the supernatant was stored at $-20^{\circ} \mathrm{C}$.

Proteins separated on 4 to $20 \%$ gradient Tris-glycine-SDS polyacrylamide gels (Invitrogen, Carlsbad, CA) were transferred onto PVDF membranes using the iBlot dry blotting system (Invitrogen), followed by immunoblotting. The membranes were blocked with $5 \%(\mathrm{wt} / \mathrm{vol}$ ) nonfat dry milk powder and probed with either GFP-specific monoclonal antibody (Clontech, Mountain View, CA) or TriMV CP antiserum (Tatineni et al. 2013) at 1:10,000 dilution. Subsequently, the membranes were probed with either anti-mouse (for GFP monoclonal antibody) or anti-rabbit (for CP antiserum) HRP conjugate at 1:50,000 dilution. The membranes were developed with Immobilon Western Chemiluminescent HRP substrate as per manufacturer's instructions (Millipore, Billerica, MA). The $\sim 56 \mathrm{kDa}$ large subunit of Rubisco protein of wheat was used as a control for the amount of protein loaded for immunoblot analyses.

Electron microscopy of virions. Virions were partially purified from $4 \mathrm{~g}$ of 14-dpi wheat tissue infected with TriMV-R as described by Tatineni et al. (2009). Partially purified virions were observed under a Hitachi H-7500 transmission electron microscope essentially as described in Tatineni et al. (2014).

Wheat curl mite transmission assays. Wheat curl mite transmission of full-length cloned and GFP-tagged viruses was performed using a single mite per test plant as described by McMechan et al. (2014) using the 'Nebraska' wheat curl mite population. Briefly, wheat seedlings inoculated at the two-leaf stage with crude extracts prepared from in vitro transcripts-infected wheat leaves, were infested with approximately 10 aviruliferous mites per source plant at $4 \mathrm{dpi}$. The source plants were maintained in individual cages and allowed a 3-week period for further propagation of mites and inoculum acquisition. Three source plants were used per virus, and single mites were transferred to 10 twoweek-old wheat seedlings for each source plant, with a total of 30 test seedlings used per virus. The test plants were kept in individual cages and incubated in a growth chamber for 3 to 4 weeks. The number of mites found on test plants was rated under a stereomicroscope, and the test plants were tested for the presence of GFP (for GFP-tagged viruses) and by direct antigen coating-enzyme-linked immunosorbent assay (DAC-ELISA) using TriMV CP antiserum (for full-length cloned viruses) (Tatineni et al. 2013).

RT-PCR assays. Total RNA extracted from wheat leaves as described by McNeil et al. (1996) was used to perform reverse transcription with random primers in a $20-\mu$ l reaction with AMV reverse transcription (Roche) (0.5 U per $\mu$ l reaction volume). One microliter of cDNA was used to perform PCR in a $25-\mu$ l reaction with Herculase II Fusion DNA polymerase (Agilent Technologies). Five microliters of PCR reaction was analyzed through $1.0 \%$ agarose gel electrophoresis in $1 \times$ TAE buffer.

\section{RESULTS}

Construction of full-length cDNA clones of TriMV. The complete TriMV genome was amplified in three overlapping cDNA fragments comprising nt 1 to 2,870 (fragment I), nt 2,801 to 6,480 (fragment II), and nt 6,401 to 10,266 plus 105 As (fragment III) (Fig. 1). The presence of unique BssHII (nt 2,831) and NsiI (nt 6,444) restriction sites in the TriMV genome facilitated the assembly of three overlapping cDNA fragments sequentially into a full-length cDNA clone, pTriMV. Nine independent full-length cDNA clones were generated in a modified pUC119 to minimize the possibility of introducing errors in cDNA fragments during RT-PCR amplification and/or propagation in E. coli. In full-length cDNA clones, the SP6 RNA polymerase promoter and 105 A residues were fused to the $5^{\prime}$ and $3^{\prime}$ ends of the genome, respectively (Fig. 1).

Infectivity of full-length cDNA clones. NotI-linearized plasmid DNAs containing the full-length cDNA of TriMV were used for in vitro transcription with SP6 RNA polymerase (Epicentre Biotechnologies, Madison, WI) in the presence of monomethylated cap analog (m7G[5']ppp[5']G; Epicentre Biotechnologies). The in vitro transcripts contained a nonviral guanosine as the first nucleotide because a guanosine residue was introduced at the transcription start site to maximize the transcript yield by SP6 RNA polymerase (Fig. 1). In vitro transcripts generated from nine independent full-length cDNA clones were inoculated onto wheat seedlings 'Tomahawk' at the single-leaf stage. RNA transcripts from three independent cDNA clones, pTriMV\#1, pTriMV\#4, and pTriMV\#81, developed symptoms in 7 to $20 \%$ of 15 to 20 inoculated plants each, with symptoms similar to those induced by the wild-type virus. However, progeny virions of these cDNA clones in crude sap from in vitro transcripts-infected wheat were highly infectious on wheat similarly to the wild-type TriMV.

Sequence analyses of pTriMV. In vitro transcripts of TriMV cDNA clones infected only 7 to $20 \%$ of wheat seedlings compared to 87 to $89 \%$ infectivity of in vitro transcripts of WSMV (Choi et al. 1999; Tatineni et al. 2014). These data suggest that the relatively low infection rates of TriMV in vitro transcripts might be due to frameshift mutations at the slippery sequences as described in Citrus tristeza virus (CTV) (Satyanarayana et al. 2003). To determine that the low infectivity of TriMV full-length cDNA clones was due to defects in sequence, pTriMV\#4 clone was completely sequenced in 
both directions. Two changes were found in the sequence of pTriMV\#4 compared with wild-type virus (GenBank accession number FJ669487). The first mutation was a synonymous mutation at nucleotide position 8236, which resulted in the change of amino acid codon CUU to CUA (leucine). The second change was a +1 frameshift at nt 3,704 with an additional ' $A$ ' residue into a homopolymeric run of seven A's, a putative shifty or transcriptional slippage sequence of the pretty interesting potyvirus ORF (PIPO) (Chung et al. 2008), resulting in a +1 frameshift of polyprotein translation that caused a stop codon at nt 4,102 . These data suggest that low infectivity of pTriMV\#4 is most likely due to a +1 frameshift found at a slippery sequence (AAAAAAC; Jacks et al. 1987).
Repair of the +1 frameshift mutation at nt 3,704 in pTriMV\#4 resulted in increased infectivity on wheat. The +1 frameshift mutation found in pTriMV\#4 at nt 3,704 was repaired in fragment II (Fig. 1) by PCR mutagenesis using pTriMV\#4 as a template to obtain pTriMV-R clones. The fragment II PCR product was digested with BssHII and NsiI and ligated into similarly digested parent clone of fragments I+III of pTriMV\#4. Transformation of the ligation mixture into E. coli strains JM109 and SURE (Agilent Technologies) resulted in two and three positive clones (pTriMV-R), respectively. Additionally, repair of the frameshift mutation in pTriMV\#4 resulted in substantial toxicity to $E$. coli that required $48 \mathrm{~h}$ to observe small colonies on agar plates.

TABLE 1. Infectivity of in vitro transcripts of Triticum mosaic virus (TriMV) full-length cDNA clones on wheat 'Tomahawk' seedlings ${ }^{\text {a }}$

\begin{tabular}{|c|c|c|c|c|c|c|}
\hline \multirow[b]{3}{*}{ Virus } & \multirow{2}{*}{\multicolumn{2}{|c|}{ Uncapped transcripts }} & \multicolumn{4}{|c|}{ Capped transcripts } \\
\hline & & & \multicolumn{2}{|c|}{ Experiment \#1 } & \multicolumn{2}{|c|}{ Experiment \#2 } \\
\hline & 14 dpi & $\%$ Infection & 14 dpi & $\%$ Infection & 14 dpi & $\%$ Infection \\
\hline pTriMV-R\#67 (SURE) & $1 / 19^{b}$ & 5 & $5 / 14$ & 35 & $11 / 17$ & 65 \\
\hline pTriMV-R\#68 (SURE) & $0 / 18$ & 0 & $10 / 22$ & 45 & $14 / 20$ & 70 \\
\hline pTriMV-R\#1 (JM109) & $0 / 18$ & 0 & $9 / 21$ & 43 & $14 / 20$ & 70 \\
\hline pTriMV-R\#2 (JM109) & $0 / 18$ & 0 & $10 / 22$ & 45 & $16 / 17$ & 94 \\
\hline pTriMV-R\#3 (JM109) & $1 / 17$ & 6 & $8 / 17$ & 47 & $12 / 18$ & 67 \\
\hline
\end{tabular}

a Wheat seedlings inoculated at the single leaf stage.

b Number of plants infected/number of plants inoculated.

A

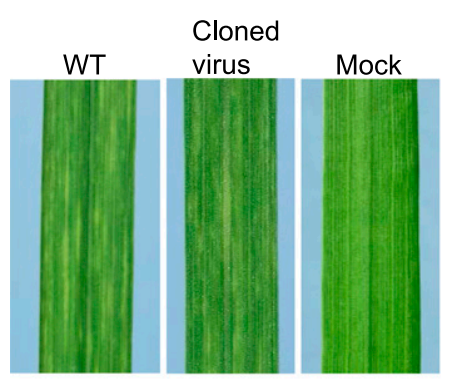

C

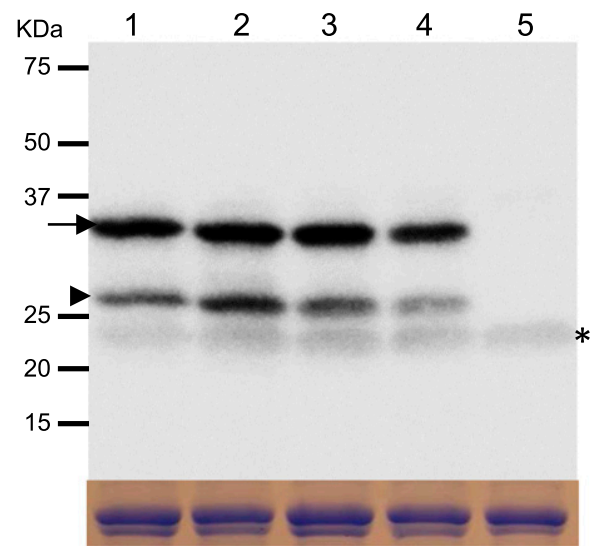

B

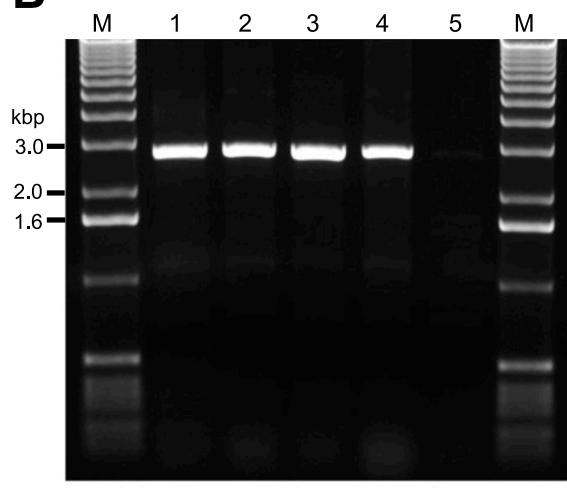

D 
Wheat seedlings inoculated with capped in vitro transcripts from NotI-linearized plasmid DNAs of repaired clones (pTriMV-R) developed mosaic and mottling symptoms in 35 to $47 \%$ and 65 to 94\% of inoculated plants in Experiment 1 and Experiment 2, respectively (Table 1). Wheat seedlings infected with in vitro transcripts of repaired cDNA clones elicited chlorotic streaks at 7 to 9 days postinoculation (dpi), followed by mosaic and mottling symptoms at 14 to $18 \mathrm{dpi}$, similar to those induced by the wild-type virus (Fig. 2A). Infection of wheat plants with in vitro transcripts of cDNA clones was confirmed by RT-PCR using a pair of primers, Tr-366 (5'-CGACGAGCGAACAAGATCATCATGCGTACG-3', corresponding to nt 1,451 to 1,480$)$ and $\mathrm{Tr}-43\left(5^{\prime}\right.$-TGCAATACA TAATCTTCATCATCTG-3', complementary to nt 4,182 to 4,158). RT-PCR amplification resulted in similar-sized products from plants infected with in vitro transcripts and wild-type virus (Fig. 2B). Western blot analysis of total proteins extracted from transcript-infected plants showed that TriMV accumulated similarly in cloned- and wild-type virus-infected plants (Fig. 2C). A truncated $\mathrm{CP}$ was observed in addition to full-length $\mathrm{CP}$ in all the samples (Fig. 2C) but authenticity of this truncated CP is not known. However, a similar truncated CP was reported in WSMV-infected wheat, and this was attributed to partial degradation of $\mathrm{CP}$ as the infection progressed (Brakke et al. 1990; Tatineni et al. 2014). Additionally, virus particles were observed in wheat leaves systemically infected with in vitro transcripts of repaired cDNA clones (Fig. 2D).

The $5^{\prime}$ end of the genomic RNAs of members of the family Potyviridae is covalently linked to a virus-encoded protein termed VPg (viral protein genome-linked) via a tyrosine residue (Murphy et al. 1991). The infectivity of uncapped in vitro transcripts of TriMV was examined as Potyviridae members facilitate capindependent translation (Carrington and Freed 1990). The uncapped in vitro transcripts of TriMV infected wheat poorly at 0 to $6 \%$ at 14 dpi (Table 1). In contrast, the uncapped in vitro transcripts of WSMV efficiently infected wheat (Choi et al. 1999). These data indicate that though the $5^{\prime}$ end of potyviral genomic RNA is not capped, TriMV in vitro transcripts synthesized with the addition of

TABLE 2. Wheat curl mite transmission of the Triticum mosaic virus (TriMV) progeny virus derived from infectious transcripts of full-length cDNA clones with a repaired +1 frameshift mutation ${ }^{\mathrm{a}}$

\begin{tabular}{|c|c|c|c|c|}
\hline Virus & $\begin{array}{l}\text { Source } \\
\text { plant }^{\mathrm{b}}\end{array}$ & $\begin{array}{l}\text { Number of plants } \\
\text { infected/number } \\
\text { of plants infested }\end{array}$ & $\begin{array}{c}\text { Percent } \\
\text { transmission }\end{array}$ & $\begin{array}{c}\text { Average } \\
\text { percent } \\
\text { transmission }\end{array}$ \\
\hline \multicolumn{5}{|l|}{ TriMV wild } \\
\hline \multirow[t]{3}{*}{ type } & 1 & $2 / 10$ & 20 & \multirow[t]{3}{*}{20} \\
\hline & 2 & $2 / 10$ & 20 & \\
\hline & 3 & $2 / 10$ & 20 & \\
\hline \multicolumn{5}{|l|}{ TriMV-R\#67 } \\
\hline \multirow[t]{3}{*}{ (SURE) } & 1 & $1 / 10$ & 10 & \multirow[t]{3}{*}{20} \\
\hline & 2 & $4 / 10$ & 40 & \\
\hline & 3 & $1 / 10$ & 10 & \\
\hline \multicolumn{5}{|l|}{ TriMV-R\#1 } \\
\hline \multirow[t]{3}{*}{ (JM109) } & 1 & $2 / 10$ & 20 & \multirow[t]{3}{*}{23} \\
\hline & 2 & $3 / 10$ & 30 & \\
\hline & 3 & $2 / 10$ & 20 & \\
\hline \multicolumn{5}{|l|}{ TriMV-R\#2 } \\
\hline \multirow[t]{3}{*}{ (JM109) } & 1 & $2 / 10$ & 20 & \multirow[t]{3}{*}{27} \\
\hline & 2 & $1 / 10$ & 10 & \\
\hline & 3 & $5 / 10$ & 50 & \\
\hline \multirow{4}{*}{$\begin{array}{l}\text { Buffer } \\
\text { inoculated } \\
\text { control }\end{array}$} & & & & \multirow{4}{*}{0} \\
\hline & 1 & $0 / 10$ & 0 & \\
\hline & 2 & $0 / 10$ & 0 & \\
\hline & 3 & $0 / 10$ & 0 & \\
\hline
\end{tabular}

a Test plants infested with a single mite transferred from each source plant. The source and test plants were assayed by direct antigen coating-enzymelinked immunosorbent assay with TriMV CP antibodies.

b The source plants were mechanically inoculated with respective progeny virus derived from transcript-inoculated wheat plants. monomethylated cap substantially improved the efficiency of infection (Table 1). Hence, all future in vitro transcripts were synthesized in the presence of monomethylated cap analog.

Progeny virus of cloned TriMV is transmitted by wheat curl mites. The progeny virus derived from in vitro transcripts of repaired TriMV cDNA clones was examined for wheat curl mite transmissibility by using the 'Nebraska' mite population as described in McMechan et al. (2014). Progeny viruses from three independent cDNA clones were transmitted by wheat curl mites with efficiencies ranging from 10 to $50 \%$ with an overall transmission rate of 20 to $27 \%$ (6 to 8 plants out of 30 test plants infected) (Table 2), which was similar to that of the wild-type virus (20\%). The test plants exposed to virus-free mites were negative for TriMV infection (Table 2). These data indicate that cloned TriMV retained wheat curl mite transmission characteristic similar to that of the wild-type virus.

GFP-tagged TriMV with seven or nine amino acid homologous NIa-Pro cleavage peptides are efficiently expressed in wheat. Experiments were designed to test whether the GFP ORF can be expressed from TriMV genome for sensitive tracking of the virus in wheat. Sequence encoding the GFP ORF was engineered into TriMV genome between the P1 and HC-Pro cistrons by fusing homologous heptapeptide NIa-Pro cleavage sites located between the $6 \mathrm{~K} 1 / \mathrm{CI}$ or $\mathrm{NIb} / \mathrm{CP}$ cistrons to the $3^{\prime}$ end of GFP to obtain TriMV-GFP-6K1/CI(7aa) and TriMV-GFPNIb/CP(7aa), respectively (Fig. 3A). Additionally, TriMV-GFP$\mathrm{NIb} / \mathrm{CP}(9 \mathrm{aa})$ was obtained by fusing GFP ORF to a nine amino acid cleavage site (heptapeptide cleavage site plus an additional spacer amino acid on either side) located between the NIb/CP cistrons (Fig. 3A). The NIa-Pro of TriMV was expected to recognize the heptapeptide cleavage sequences in trans and was predicted to cleave between the 6th (P1 position) and 7th (P1' position) amino acids of the heptapeptide cleavage site (Adams et al. 2005). Hence, the first six amino acids of the heptapeptide cleavage site formed part of the C-terminus of GFP and the 7th amino acid formed the first amino acid of HC-Pro (Fig. 3A). At least one nucleotide of each amino acid codon was changed to avoid possible homologous recombination due to duplicated cleavage peptide sequences in the TriMV genome.

In vitro transcripts of TriMV-GFP-6K1/CI(7aa), TriMV-GFP$\mathrm{NIb} / \mathrm{CP}(7 \mathrm{aa})$, and TriMV-GFP-NIb/CP(9aa) infected wheat similarly to the wild-type virus at 60 to $90 \%$ efficiency. GFP-tagged viruses developed chlorotic streaks at 7 to $9 \mathrm{dpi}$, followed by mosaic and mottling symptoms similar to those of the wild-type or cloned virus. Observation of wheat leaves infected with GFP-tagged viruses under a stereo-fluorescence microscope revealed that GFP formed bright fluorescent foci on inoculated leaves (Fig. 3B). In upper noninoculated leaves, GFP was observed as bright fluorescence in the veins at 7 to $9 \mathrm{dpi}$, followed by fluorescence covering most of the leaf lamina at 14 to $18 \mathrm{dpi}$ (Fig. 3B). GFP fluorescence was observed in inoculated (local foci) and noninoculated (systemic infection) leaves with little or no aggregate-like fluorescent structures (Fig. 3B and C). Examination of wheat leaves infected with TriMV-GFP-6K1/CI(7aa), TriMV-GFP-NIb/CP(7aa), and TriMVGFP-NIb/CP(9aa) under a confocal microscope revealed that GFP fluorescence formed as a free soluble protein mostly restricted to cytoplasm, cell membrane, nucleus, and cytoplasmic strands of the cell (Fig. 3C).

Examination of the GFP accumulation profile in wheat leaves infected with TriMV-GFP vectors with heptapeptide cleavage sites found predominantly the $27 \mathrm{kDa}$ GFP and smaller amounts of the $\sim 75$ kDa putative GFP:HC-Pro fusion protein (Fig. 3D, lanes 4 and 5). In TriMV-GFP-NIb/CP(9aa)-infected wheat, complete cleavage of GFP from HC-Pro was observed with no detectable accumulation of GFP:HC-Pro fusion protein (Fig. 3D, lane 6).

TriMV-GFP vectors are stable in wheat. The stability of the GFP ORF in TriMV-GFP-6K1/CI(7aa), TriMV-GFP-NIb/ $\mathrm{CP}(7 \mathrm{aa})$, and TriMV-GFP-NIb/CP(9aa) was examined by determining 
the retention of the GFP sequence through varying time periods in the wheat plant and through multiple serial passages of the TriMVGFP vectors (Fig. 4). Wheat seedlings were inoculated with in vitro transcripts of two independent clones for each GFP-tagged vector and total RNA was extracted at 75, 105, and 120 dpi. All six GFPtagged viruses, two clones per construct, were stable at 75 and 105 dpi (Fig. 4A). At 120 dpi, both clones of TriMV-GFP-NIb/CP(9aa) retained the GFP insert with no detectable truncated RT-PCR

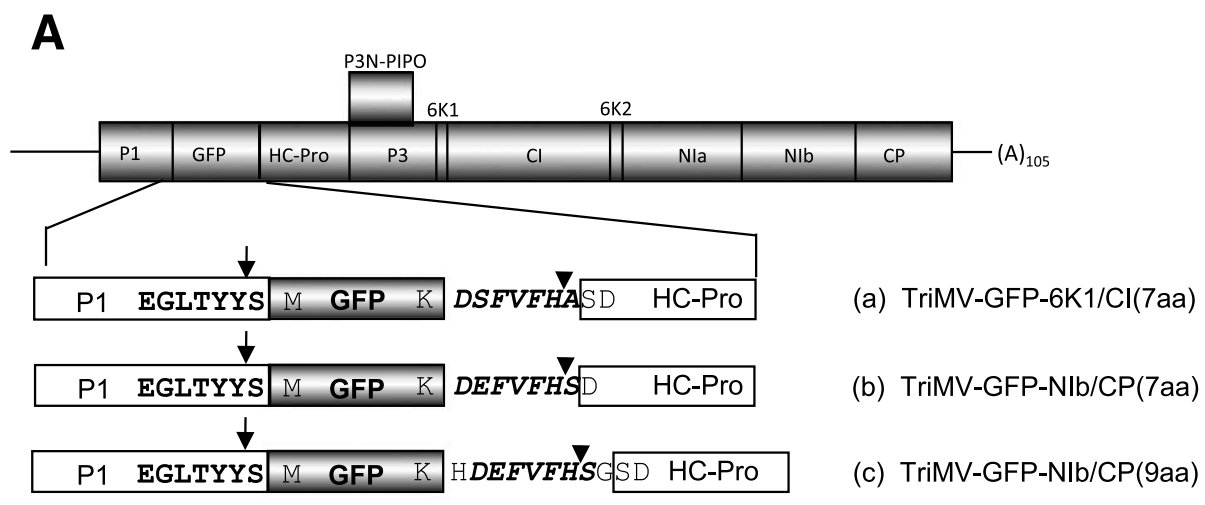

B
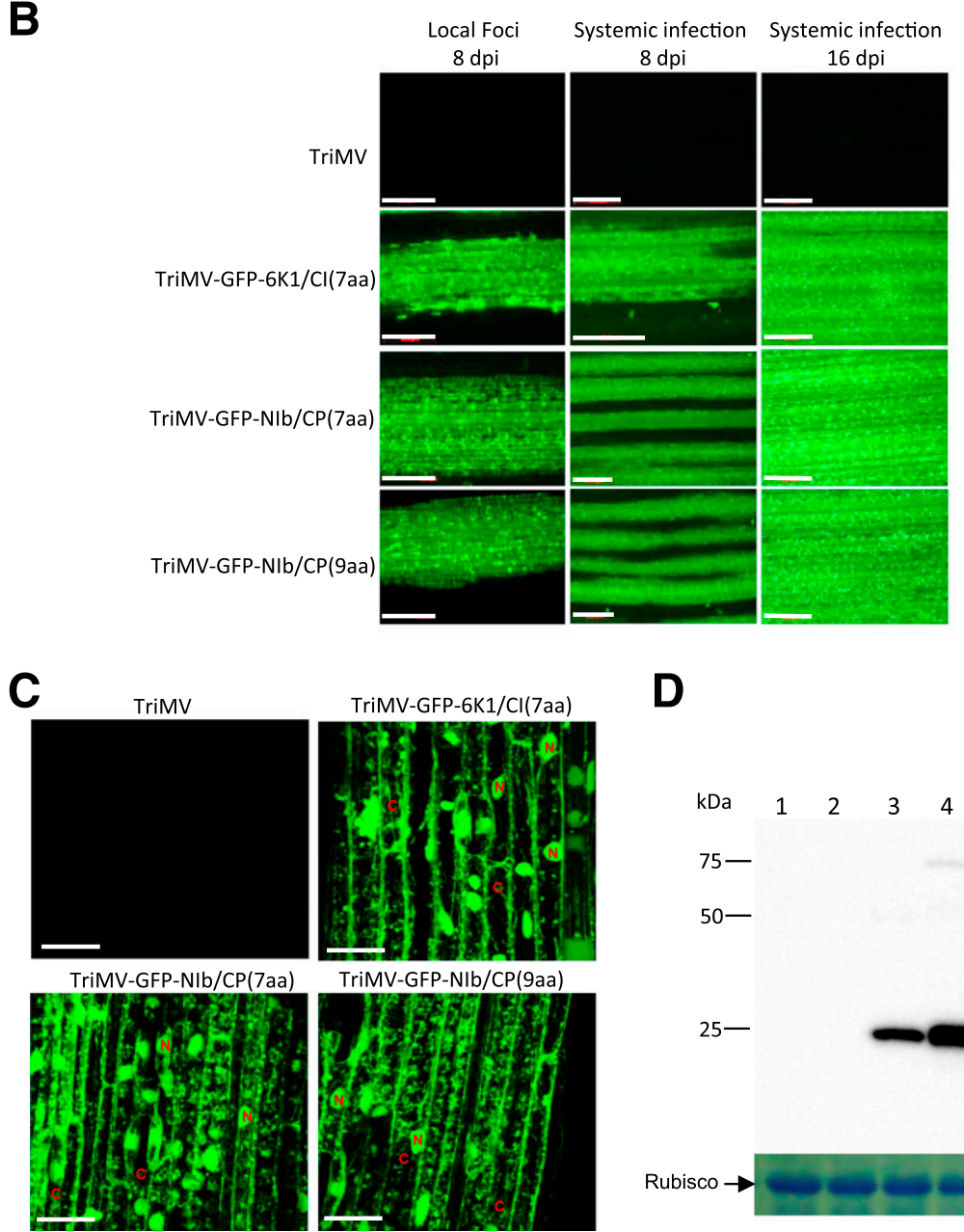

D

TriMV-GFP-NIb/CP(9aa)
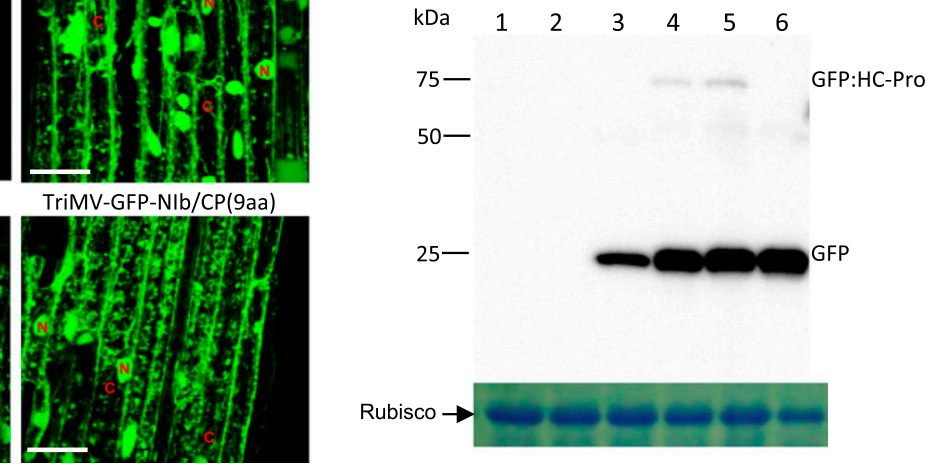

Fig. 3. Development of green fluorescent protein (GFP)-tagged Triticum mosaic virus (TriMV) vectors with homologous NIa-Pro cleavage peptides. A, Schematic diagram of TriMV genome with GFP open reading frame (ORF) engineered between P1 and HC-Pro cistrons. The enlarged view of GFP ORF in TriMV genome is indicated with the C- and N-terminal junctions of P1 and HC-Pro, respectively. The position of cleavage by P1 proteinase between P1 and GFP is indicated with an arrow, and the position of cleavage by NIa-Pro between the C-terminus of GFP and the N-terminus of HC-Pro is indicated with an arrowhead. The first and last amino acids of GFP are indicated. TriMV-GFP vectors were engineered with the NIa-Pro heptapeptide cleavage site located between $6 \mathrm{~K} 1 / \mathrm{CI}$ (a) and NIb/CP (b) cistrons, and with one spacer amino acid on either side of the heptapeptide cleavage site located between the NIb/CP cistrons (c). B, Expression of GFP in inoculated ( 8 days postinoculation [dpi]) and upper noninoculated ( 8 and $16 \mathrm{dpi}$ ) wheat leaves infected with TriMV-GFP vectors. Wheat leaves were observed under Stereo Discovery V12 Fluorescence Microscope. Bars represent $500 \mu \mathrm{M}$. C, Examination of GFP expression under confocal microscope in 14 dpi wheat leaves systemically infected with GFP-tagged TriMV as indicated. Bars represent $50 \mu \mathrm{M}$. N: nucleus, C: cytoplasmic strands. D, Western blot analysis of total proteins from wheat leaves at 18 dpi with a GFP-specific monoclonal antibody. The position of free GFP and GFP:HC-Pro fusion protein, and protein molecular weight standards are indicated at the right and left side of the blot, respectively. Healthy wheat (lane 1), TriMV (lane 2), GFP control, 2.5 ng diluted in healthy wheat sap (lane 3), TriMVGFP-6K1/CI(7aa) (lane 4), TriMV-GFP-NIb/CP(7aa) (lane 5), and TriMV-GFP-NIb/CP(9aa) (lane 6). A Coomassie Brilliant Blue-stained sodium dodecyl sulfatepolyacrylamide gel electrophoresis showing the large subunit of Rubisco protein of wheat was used as a control for the amount of protein loaded for western blot analysis. 
product. In contrast, the GFP insert was stable in one clone of TriMV-GFP-NIb/CP(7aa) but not in the second clone. Both clones of TriMV-GFP-6K1/CI(7aa) lost the GFP insert either completely or partially by $120 \mathrm{dpi}$ (Fig. 4A). In another method, progeny viruses derived from wheat leaves infected with in vitro transcripts of GFP-tagged TriMV were passaged serially in wheat at $14 \mathrm{dpi}$ intervals for six passages by mechanical inoculation. All three GFP vectors were stable for six passages with no detectable loss of GFP insert (Fig. 4B). Taken together, these data indicate that TriMVGFP-NIb/CP(9aa) is highly stable in wheat, followed by TriMVGFP-NIb/CP(7aa) and TriMV-GFP-6K1/CI(7aa).

GFP-tagged TriMV was efficiently transmitted by wheat curl mites. Wheat curl mite transmission of TriMV-GFP-6K1/CI (7aa), TriMV-GFP-NIb/CP(7aa) and TriMV-GFP-NIb/CP(9aa) was performed as described in McMechan et al. (2014) using the 'Nebraska' mite population. All three TriMV-GFP vectors were transmitted at 40 to $47 \%$ compared with $53 \%$ of the wild-type virus (Table 3). TriMV-GFP-6K1/CI(7aa) was transmitted from 30 to $80 \%$ with an overall transmission efficiency of $47 \%$. Transmission efficiency of TriMV-NIb/CP(7aa) was 30 to $70 \%$ with an average transmission rate of $43 \%$. TriMV-GFP-NIb/CP(9aa) was transmitted at 30 to $50 \%$ efficiency with an overall transmission rate of $40 \%$ (Table 3 ). These data demonstrated that GFP-tagged TriMV with seven or nine amino acid cleavage peptides was transmitted by wheat curl mites similarly to the wildtype virus.

RFP was efficiently expressed from TriMV. We next engineered an RFP ORF (Campbell et al. 2002) between the P1 and HC-Pro cistrons to create TriMV-RFP-NIb/CP(9aa) (Fig. 5A). Since the TriMV GFP vector with a 9-amino acid cleavage peptide located between the NIb/CP cistrons more stably expressed GFP compared with other cleavage sites, we used this cleavage peptide to release RFP from HC-Pro (Fig. 5A). In vitro transcripts of TriMVRFP-NIb/CP(9aa) infected wheat similarly to those of TriMV-GFP vectors and expressed RFP with uniform distribution in infected wheat cells (Fig. 5B). Expression of RFP was observed in stems, leaves, and crowns of wheat plants at $14 \mathrm{dpi}$ (Fig. 5B). The stability of RFP ORF in TriMV genome was examined by RT-PCR, and found that TriMV-RFP-NIb/CP(9aa) retained the RFP ORF in infected wheat for more than 120 days, similar to that of TriMVGFP-NIb/CP(9aa) (data not shown).

\section{A}

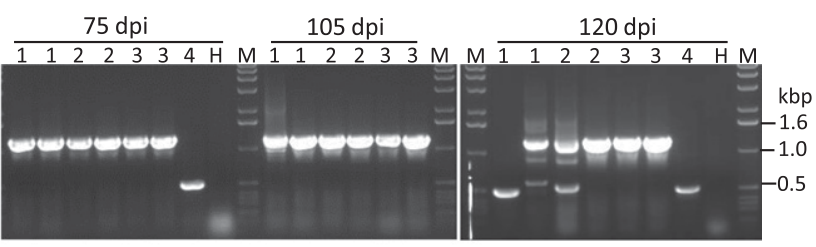

B

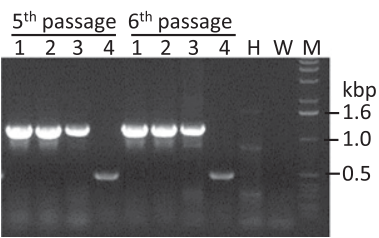

Fig. 4. Stability of Triticum mosaic virus (TriMV)-green fluorescent protein (GFP) vectors in wheat. Examination of the stability of TriMV-GFP vectors by reverse transcription-polymerase chain reaction amplification with primers flanking the GFP open reading frame in the TriMV genome A, at 75, 105, and 120 days postinoculation (dpi) and $\mathbf{B}$, at the 5 th and 6 th serial passage. Two independent clones per TriMV-GFP construct were used for GFP stability assay in A. TriMV-GFP-6K1/CI(7aa) (lanes 1), TriMV-GFP-NIb/CP(7aa) (lanes 2), TriMV-GFP-NIb/CP(9aa) (lanes 3), TriMV (lane 4), healthy wheat (lane $\mathrm{H}$ ), water control (lane $\mathrm{W}$ ), and 1-kbp DNA ladder (lane M).

\section{DISCUSSION}

Most members of the family Potyviridae are recalcitrant to develop reverse genetic systems due to the inherent toxicity of virus-encoded proteins to E. coli (Boyer and Haenni 1994). Here, we report the development of stable infectious cDNA clones of TriMV, the type member of the genus Poacevirus, in a high-copynumber plasmid. Additionally, the infectious cDNA clone was engineered to express GFP or RFP between the P1 and HC-Pro cistrons by fusing homologous NIa-Pro cleavage peptides to the C-terminus of fluorescent proteins. GFP- or RFP-tagged TriMV vectors stably expressed fluorescent proteins in wheat for more than 120 dpi and six serial passages by mechanical inoculation.

Initially, we observed that in vitro transcripts of three out of nine full-length cDNA clones in pUC119 inefficiently infected wheat. Nucleotide sequence analysis of one of these cDNA clones revealed that the poor infection rate of TriMV cDNA clone was likely due to $\mathrm{a}+1$ frameshift, resulting in an additional $\mathrm{A}$ in the AAAAAAAC sequence located between nt 3,695 and 3,702. Nucleotide sequence of TriMV genome from progeny virions revealed that +1 frameshift within the A stretch was spontaneously repaired during replication in wheat. The TriMV cDNA clone with the AAAAAAAAC sequence, harboring an additional A (+1 frameshift), most likely acts as a slippery sequence for continuous translation, albeit at reduced levels, might have contributed to the initially poor infection of wheat seedlings as observed with CTV infectious cDNA clone (Satyanarayana et al. 2003).

However, repair of the +1 frameshift mutation in TriMV cDNA clone resulted in increased toxicity to E. coli strains JM109 and SURE, both of which required $48 \mathrm{~h}$ to grow on agar plates. Similar levels of increased toxicity to $E$. coli have been observed in the +1 frameshift mutation repaired clones of CTV (Satyanarayana et al. 2003). The increased toxicity of repaired cDNA clones to E. coli could be due to enhanced accumulation of virus-encoded translation products that are toxic to E. coli. The stability of TriMV

TABLE 3. Wheat curl mite transmission of the green fluorescent protein (GFP)-tagged Triticum mosaic virus (TriMV) progeny virus derived from in vitro transcripts of cDNA clones ${ }^{\mathrm{a}}$

\begin{tabular}{|c|c|c|c|c|}
\hline Mutant & $\begin{array}{c}\text { Source } \\
\text { plant }^{\mathrm{b}}\end{array}$ & $\begin{array}{l}\text { Number of plants } \\
\text { infected/number } \\
\text { of plants infested }\end{array}$ & $\begin{array}{c}\text { Percent } \\
\text { transmission }\end{array}$ & $\begin{array}{c}\text { Average } \\
\text { percent } \\
\text { transmission }\end{array}$ \\
\hline \multicolumn{5}{|l|}{ TriMV-wild } \\
\hline \multirow[t]{3}{*}{ type } & 1 & $7 / 10$ & 70 & 53 \\
\hline & 2 & $6 / 10$ & 60 & \\
\hline & 3 & $3 / 10$ & 30 & \\
\hline \multicolumn{5}{|l|}{ TriMV-GFP- } \\
\hline \multirow[t]{3}{*}{$6 \mathrm{~K} 1 / \mathrm{CI}(7 \mathrm{aa})$} & 1 & $3 / 10$ & 30 & 47 \\
\hline & 2 & $8 / 10$ & 80 & \\
\hline & 3 & $3 / 10$ & 30 & \\
\hline \multicolumn{5}{|l|}{ TriMV-GFP- } \\
\hline \multirow[t]{3}{*}{$\mathrm{NIb} / \mathrm{CP}(7 \mathrm{aa})$} & 1 & $7 / 10$ & 70 & 43 \\
\hline & 2 & $3 / 10$ & 30 & \\
\hline & 3 & $3 / 10$ & 30 & \\
\hline \multicolumn{5}{|l|}{ TriMV-GFP- } \\
\hline \multirow[t]{3}{*}{$\mathrm{NIb} / \mathrm{CP}(9 \mathrm{aa})$} & 1 & $5 / 10$ & 50 & 40 \\
\hline & 2 & $4 / 10$ & 40 & \\
\hline & 3 & $3 / 10$ & 30 & \\
\hline \multicolumn{5}{|l|}{$\begin{array}{l}\text { Buffer } \\
\text { inoculated }\end{array}$} \\
\hline \multirow[t]{3}{*}{ control } & 1 & $0 / 10$ & 0 & 0 \\
\hline & 2 & $0 / 10$ & 0 & \\
\hline & 3 & $0 / 10$ & 0 & \\
\hline
\end{tabular}

a Single mite transmissions were performed from each source plant. The source and test plants were assayed for the presence of GFP fluorescence or by direct antigen coating-enzyme-linked immunosorbent assay with TriMV CP antibodies.

b The source plants were mechanically inoculated with respective progeny virus derived from transcript-inoculated wheat plants. 
cDNA in pUC119 was increased by propagating E. coli at $30^{\circ} \mathrm{C}$ with no detectable aberrations in viral cDNA. In vitro transcripts generated from repaired cDNA clones that efficiently infected wheat, and the progeny virus was transmitted by wheat curl mites similarly to wild-type virus, indicating that the infectious cDNA clone retained the cell-to-cell and long-distance movement, pathogenicity, and vector transmission characteristics. The functions of TriMV-encoded proteins are not known with the exception of the P1 protein in suppressing host RNA silencing (Tatineni et al. 2012) and the coat protein for virion assembly. It is likely that some of the virus-encoded proteins might possess multiple roles. The availability of a reverse genetics system for TriMV provides a powerful tool to examine the functions of TriMV-encoded proteins and the unique 5' leader sequence/structure in virus biology.

Development of GFP-tagged viruses facilitated the examination of virus movement and disease development (Cohen et al. 2000; Oparka et al. 1997; Tatineni and Dawson 2012; Tatineni et al. 2014). Virus induced gene silencing vectors have been developed for Brome mosaic virus and Barley stripe mosaic virus vectors for functional genomic studies in monocotyledonous hosts (Ding et al. 2006; Holzberg et al. 2002; Yuan et al. 2011). Herein, we developed TriMV-based expression vectors by engineering GFP or RFP encoding sequence into the TriMV genome between the P1 and HC-Pro cistrons by fusing homologous NIa-Pro cleavage peptides to the $3^{\prime}$ end of GFP or RFP ORF. The TriMV NIa-Pro facilitated efficient cleavage of GFP fused to the heptapeptide cleavage site and resulted in free $(27 \mathrm{kDa})$ fluorescent protein in wheat. In other potyviruses, the heptapeptide cleavage sites were identified as the minimal cleavage peptide required for efficient cleavage by NIaPro (Adams et al. 2005; Carrington and Dougherty, 1988; Carrington et al. 1988; Domier et al. 1987). In this study, we also found that heptapeptide cleavage sites of TriMV are sufficient for efficient cleavage by NIa-Pro.

TriMV-based vectors with a heptapeptide or with a nine amino acid cleavage peptide retained the GFP ORF for 105 and 120 dpi, respectively, and retained the GFP insert for more than six serial passages at 14-day intervals with no detectable loss of insert. These data indicate that TriMV vectors with seven or nine amino acid

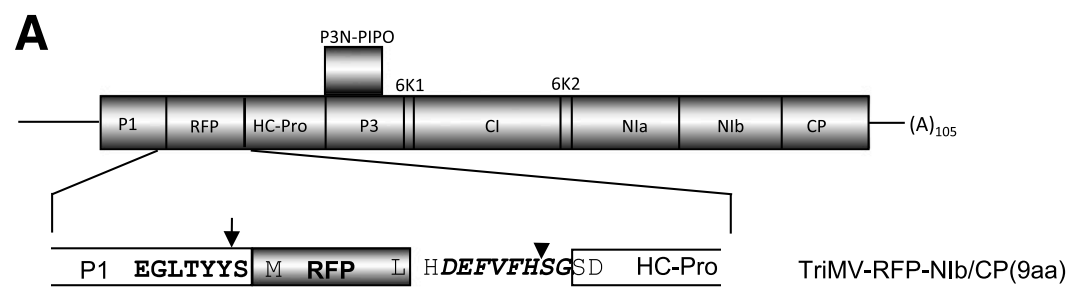

\section{B}

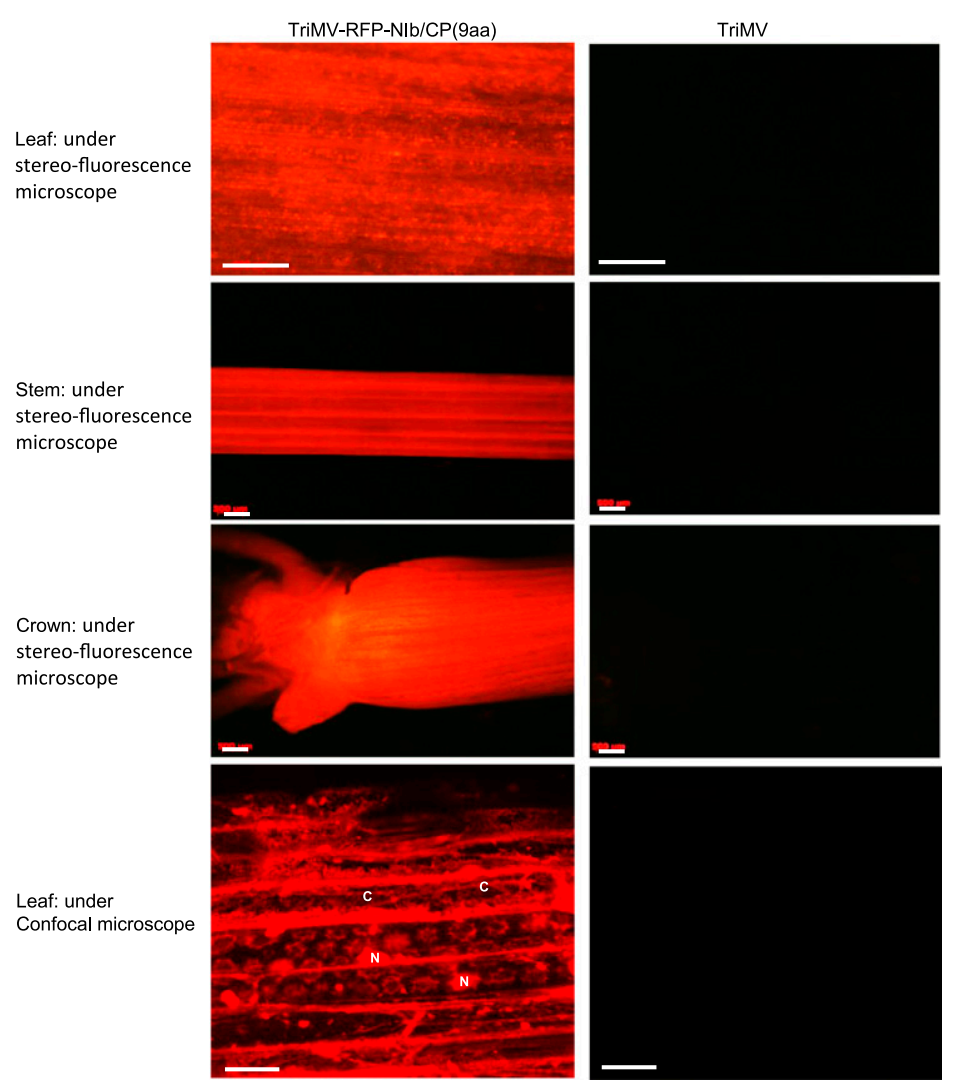

Fig. 5. Development of red fluorescent protein (RFP)-tagged Triticum mosaic virus (TriMV). A, Genome organization of TriMV with RFP open reading frame (ORF) between P1 and HC-Pro cistrons. An expanded view of RFP in the TriMV genome with the C-terminus of P1 and N-terminus of HC-Pro is indicated below the genomic organization. The heptapeptide cleavage site located between NIb/CP cistrons with one spacer amino acid on either side was fused to the C-terminus of RFP for efficient cleavage by NIa-Pro. The cleavage peptides of P1 and NIa-Pro (located between the NIb/CP cistrons) are indicated in bold and italic bold, respectively. B, Expression of RFP in wheat at 18 days postinoculation (dpi) in leaves, stems, and crowns was observed under a stereo-fluorescent microscope. Bars represent $500 \mu \mathrm{m}$. Expression of RFP in TriMV-RFP-NIb/CP(9aa)-infected wheat leaves at 18 dpi was observed under confocal microscope. Bars represent $50 \mu \mathrm{M}$. $\mathrm{N}$ : nucleus, C: cytoplasmic strands. 
cleavage peptides are stable considering the $\sim 120$-day life-span of wheat. The insertion of foreign sequences into viral genomes can have significant effects on virus replication, movement, and pathogenicity (Choi et al. 2000; Shivprasad et al. 1999). GFP- or RFP-tagged TriMV elicited symptoms and were transmitted by wheat curl mites similarly to the wild-type virus, showing that the TriMV genome tolerated insertion of $\sim 700$ nt GFP or RFP sequence. Though TriMV vectors with GFP or RFP inserts are relatively stable, it is possible that inserts with more than $1,000 \mathrm{nt}$ might affect the stability of the vector.

TriMV elicits relatively mild mosaic and mottling symptoms on wheat compared with severe chlorotic streaks, leaf yellowing, and stunting by WSMV (Seifers et al. 2008; Stenger et al. 1998). Differential symptom phenotypes of TriMV and WSMV will facilitate the examination of the roles of WSMV proteins in disease development by expressing WSMV cistrons in TriMV. Furthermore, the availability of GFP- or RFP-tagged TriMV (this study) and GFP-tagged WSMV (Tatineni et al. 2011) will enable the definition of the mechanisms of disease synergy in wheat co-infected by WSMV and TriMV.

\section{ACKNOWLEDGMENTS}

We thank C. Aldrich and J. Horrell for their technical assistance, C. Elowsky for his help with confocal microscopy, and R. French for stimulating discussions during the course of this investigation. This project was supported in part by funds provided through the United States Department of Agriculture, USDA-NIFA grant number 2013-68004-20358. Mention of trade names or commercial products in this publication is solely for the purpose of providing specific information and does not imply recommendation or endorsement by the U.S. Department of Agriculture.

\section{LITERATURE CITED}

Adams, M. J., Antoniw, J. F., and Beaudoin, F. 2005. Overview and analysis of the polyprotein cleavage sites in the family Potyviridae. Mol. Plant Pathol. 6:471-487.

Ahlquist, P., French, R., Janda, M., and Loesch-Fries, L. S. 1984. Multicomponent RNA plant virus infection derived from cloned viral cDNA. Proc. Natl. Acad. Sci. USA 81:7066-7070.

Boyer, J. C., and Haenni, A. L. 1994. Infectious transcripts and cDNA clones of RNA viruses. Virology 198:415-426.

Brakke, M. K., Skopp, R. N., and Lane, L. C. 1990. Degradation of Wheat streak mosaic virus capsid protein during leaf senescence. Phytopathology 80:1401-1405

Burch-Smith, T. M., Anderson, J. C., Martin, G. B., and Dinesh-Kumar, S. P. 2004. Applications and advantages of virus-induced gene silencing for gene function studies in plants. Plant J. 39:734-746.

Burrows, M., Franc, G., Rush, C., Blunt, T., Ito, D., Kinzer, K., Olson, J., O’Mara, J., Price, J., Tande, C., Ziems, A., and Stack, J. 2009. Occurrence of viruses in wheat in the Great Plains region 2008. Plant Health Progress. Published online. doi:10.1094/PHP-2009-0706-01-RS.

Byamukama, E., Seifers, D. L., Hein, G. L., De Wolf, E., Tisserat, N. A., Langham, M. A. C., Osborne, L. E., Timmerman, A., and Wegulo, S. N. 2013. Occurrence and distribution of Triticum mosaic virus in the central Great Plains. Plant Dis. 97:21-29.

Campbell, R. E., Tour, O., Palmer, A. E., Steinbach, P. A., Baird, G. S., Zacharias, D. A., and Tsien, R. Y. 2002. A monomeric red fluorescent protein. Proc. Natl. Acad. Sci. USA 99:7877-7882.

Carrington, J. C., Cary, S. M., and Dougherty, W. G. 1988. Mutational analysis of tobacco etch virus polyprotein processing: cis and trans proteolytic activities of polyproteins containing the 49-kilodalton proteinase. J. Virol. 62:2313-2320.

Carrington, J. C., and Dougherty, W. G. 1988. A viral cleavage site cassette: Identification of amino acid sequences required for tobacco etch virus polyprotein processing. Proc. Natl. Acad. Sci. USA 85:3391-3395.

Carrington, J. C., and Freed, D. D. 1990. Cap-independent enhancement of translation by a plant potyvirus 5' nontranslated region. J. Virol. 64:1590-1597.

Choi, I. R., French, R., Hein, G. L., and Stenger, D. C. 1999. Fully biologically active in vitro transcripts of the eriophyid mite-transmitted Wheat streak mosaic tritimovirus. Phytopathology 89:1182-1185.

Choi, I. R., Stenger, D. C., Morris, T. J., and French, R. 2000. A plant virus vector for systemic expression of foreign genes in cereals. Plant J. 23:547-555.

Chung, B. Y.-W., Miller, W. A., Atkins, J. F., and Firth, A. E. 2008. An overlapping essential gene in the Potyviridae. Proc. Natl. Acad. Sci. USA 105:5897-5902.
Cohen, Y., Gisel, A., and Zambryski, P. C. 2000. Cell-to-cell and systemic movement of recombinant green fluorescent protein-tagged Turnip crinkle viruses. Virology 273:258-266.

Dawson, W. O., Beck, D. L., Knorr, D. A., and Grantham, G. L. 1986. cDNA cloning of the complete genome of Tobacco mosaic virus and production of infectious transcripts. Proc. Natl. Acad. Sci. USA 83:5043-5047.

Ding, X. S., Schneider, W. L., Chaluvadi, S. R., Mian, M. A. R., and Nelson, R. S. 2006. Characterization of a Brome mosaic virus strain and its use as a vector for gene silencing in monocotyledous hosts. Mol. Plant-Microbe Interact. 19:1229-1239.

Domier, L. L., Shaw, J. G., and Rhoads, R. E. 1987. Potyviral proteins share amino acid sequence homology with picarno-, como-, and caulimoviral proteins. Virology 158:20-27.

Fakhfakh, H., Vilaine, F., Makni, M., and Robaglia, C. 1996. Cell-free cloning and biolistic inoculation of an infectious cDNA of Potato virus Y. J. Gen. Virol. 77:519-523.

Fellers, J. P., Seifers, D., Ryba-White, M., and Martin, T. J. 2009. The complete genome sequence of Triticum mosaic virus, a new wheat-infecting virus of the High Plains. Arch. Virol. 154:1511-1515.

Gleba, Y., Klimyuk, V., and Marillonnet, S. 2007. Viral vectors for the expression of proteins in plants. Curr. Opin. Biotechnol. 18:134-141.

Ho, S. N., Hunt, H. D., Horton, R. M., Pullen, J. K., and Pease, L. R. 1989. Site directed mutagenesis by overlap extension using the polymerase chain reaction. Gene 77:51-59.

Holzberg, S., Brosio, P., Gross, C., and Pogue, G. P. 2002. Barley stripe mosaic virus-induced gene silencing in a monocot plant. Plant J. 30:315-327.

Jacks, T., Townsley, K., Varmus, H. E., and Majors, J. 1987. Two efficient ribosomal frameshifting events are required for synthesis of Mouse mammary tumor virus gag-related polyproteins. Proc. Natl. Acad. Sci. USA 84:4298-4302.

Johansen, I. E. 1996. Intron insertion facilitates amplification of cloned virus cDNA in Escherichia coli while biological activity is reestablished after transcription in vivo. Proc. Natl. Acad. Sci. USA 93:12400-12405.

López-Moya, J. J., and García, J. A. 2000. Construction of stable and highly infectious intron-containing cDNA clone of plum pox potyvirus and its use to infect plants by particle bombardment. Virus Res. 68:99-107.

McMechan, A. J., Tatineni, S., French, R., and Hein, G. L. 2014. Differential transmission of Triticum mosaic virus by wheat curl mite populations collected in the Great Plains. Plant Dis. 98:806-810.

McNeil, J. E., French, R., Hein, G. L., Baenziger, P. S., and Eskridge, K. M. 1996. Characterization of genetic variability among natural populations of Wheat streak mosaic virus. Phytopathology 86:1222-1227.

Murphy, J. F., Rychlik, W., Rhoads, R. E., Hunt, A. G., and Shaw, J. G. 1991. A tyrosine residue in the small nuclear inclusion protein of tobacco vein mottling virus links the VPg to the viral RNA. J. Virol. 65:511-513.

Oparka, K. J., Roberts, A. G., SantaCruz, S., Boevink, P., Prior, D. A. M., and Smallcombe, A. 1997. Using GFP to study virus invasion and spread in plant tissues. Nature 388:401-402.

Satyanarayana, T., Gowda, S., Ayllon, M. A., and Dawson, W. O. 2003. Frameshift mutations in infectious cDNA clones of Citrus tristeza virus: A strategy to minimize the toxicity of viral sequences to Escherichia coli. Virology 313:481-491.

Scholthof, H. B., Morris, T. J., and Jackson, A. O. 1993. The capsid protein gene of Tomato busy stunt virus is dispensable for systemic movement and can be replaced for localized expression of foreign genes. Mol. Plant-Microbe Interact. 6:309-322.

Seifers, D. L., Martin, T. J., Harvey, T. L., Fellers, J. P., and Michaud, J. P. 2009. Identification of the wheat curl mite as the vector of Triticum mosaic virus. Plant Dis. 93:25-29.

Seifers, D. L., Martin, T. J., Harvey, T. L., Fellers, J. P., Stack, J. P., Ryba-White, M., Haber, S., Krokhin, O., Spicer, V., Lovat, N., Yamchuk, A., and Standing, K. G. 2008. Triticum mosaic virus: A new virus isolated from wheat in Kansas. Plant Dis. 92:808-817.

Shivprasad, S., Pogue, G. P., Lewandowski, D. J., Hidalgo, J., Donson, J., Grill, L. K., and Dawson, W. O. 1999. Heterologous sequences greatly affect foreign gene expression in Tobacco mosaic virus-based vectors. Virology 255:312-323.

Stenger, D. C., Hall, J. S., Choi, I. R., and French, R. 1998. Phylogenetic relationships within the family Potyviridae: Wheat streak mosaic virus and Brome streak mosaic virus are not members of the genus Rymovirus. Phytopathology 88:782-787.

Stewart, L. R., Bouchard, R., Redinbaugh, M. G., and Meulia, T. 2012. Complete sequence and development of a full-length infectious clone of an Ohio isolate of Maize dwarf mosaic virus (MDMV). Virus Res. 165:219-224.

Tatineni, S., and Dawson, W. O. 2012. Enhancement or attenuation of disease by deletion of genes from Citrus tristeza virus. J. Virol. 86:7850-7857.

Tatineni, S., Graybosch, R. A., Hein, G. L., Wegulo, S. N., and French, R. 2010. Wheat cultivar-specific disease synergism and alteration of virus accumulation during co-infection with Wheat streak mosaic virus and Triticum mosaic virus. Phytopathology 100:230-238. 
Tatineni, S., Kovacs, F., and French, R. 2014. Wheat streak mosaic virus infects systemically despite extensive coat protein deletions: Identification of virion assembly and cell-to-cell movement determinants. J. Virol. 88: 1366-1380.

Tatineni, S., McMechan, A. J., Hein, G. L., and French, R. 2011. Efficient and stable expression of GFP through Wheat streak mosaic virus-based vectors in cereal hosts using a range of cleavage sites: Formation of dense fluorescent aggregates for sensitive virus tracking. Virology 410: 268-281.

Tatineni, S., Qu, F., Li, R., Morris, T. J., and French, R. 2012. Triticum mosaic poacevirus enlists $\mathrm{P} 1$ rather than $\mathrm{HC}$-Pro to suppress RNA silencingmediated host defense. Virology 433:104-115.

Tatineni, S., Sarath, G., Seifers, D., and French, R. 2013. Immunodetection of Triticum mosaic virus by DAS- and DAC-ELISA using antibodies produced against coat protein expressed in Escherichia coli: Potential for highthroughput diagnostic methods. J. Virol. Methods 189:196-203.

Tatineni, S., Ziems, A. D., Wegulo, S. N., and French, R. 2009. Triticum mosaic virus: A distinct member of the family Potyviridae with an unusually long leader sequence. Phytopathology 99:943-950.

Wylie, S. J., Tan, A. J. Y., Li, H., Dixon, K. W., and Jones, M. G. K. 2012. Caladenia virus $A$, an unusual new member of the family Potyviridae from terrestrial orchids in Western Australia. Arch. Virol. 157:2447-2452.

Xu, D.-L., Zhou, G.-H., Xie, Y.-J., Mock, R., and Li, R. 2010. Complete nucleotide sequence and taxonomy of Sugarcane streak mosaic virus, member of a novel genus in the family Potyviridae. Virus Genes 40:432-439.

Yuan, C., Li, C., Yan, L., Jackson, A. O., Liu, Z., Han, C., Yu, J., and Li, D. 2011. A high throughput Barley stripe mosaic virus vector for virus induced gene silencing in monocots and dicots. PLoS One 6:e26468. 